\title{
EUROPEAN REGULATION OF INSOLVENCY STATUS IN THE HYBRID PROCEEDING
}

\author{
Tomáš Moravec ${ }^{*}$ Jan Pastorčák ${ }^{* *} \&$ Petr Valenta ${ }^{* * *}$
}

\begin{abstract}
The paper deals with the establishment of insolvency status in the hybrid proceeding under proposal of the Regulation No. 1346/2000 revision. The one of main problems of European Insolvency law is that the hybrid proceedings are not regulated by any regulation or directive now. The proposal of the Regulation No. 1346/2000 revision broadens its scope and includes hybrid proceeding in opt-out way. The criterions for establishing of the insolvency statute in the hybrid proceeding are set by national regulations across the European Union currently. The criterions are different and could cause legal uncertainty. So the paper also focuses on the insolvency status in the hybrid proceeding in the current situation and after adopting proposed legislative amendment. The paper is based on factual analysis of legislation and structural analysis of court decisions. The paper also confirms proposed hypothesis that the pre-insolvency and the hybrid proceeding should be covered by the Regulation No. 1346/2000.
\end{abstract}

INTRODUCTION

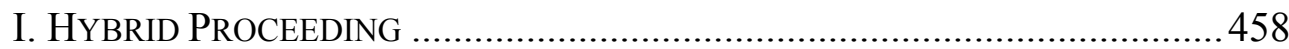

A. Hybrid Proceeding in the Member States................................ 459

B. Hybrid Proceeding in Case Law.............................................. 460

II. THE INSOLVENCY STATUS IN THE HYBRID PROCEEDING ..........................462

A. $\quad$ The Current Legislation............................................................... 463

B. $\quad$ The Proposed Legislation .......................................................... 464



\section{INTRODUCTION}

European insolvency law is regulated on European level by different regulations and directives. The European Regulation No. 1346/2000 ${ }^{1}$ concerns to collective insolvency proceedings which entail the partial or total divestment of a debtor and the appointment of a liquidator (Regulation No. 1346/2000, art. 1). From the regime of the Regulation No. 1346/2000 are excluded insolvency proceedings concerning insurance undertakings,

\footnotetext{
* Tomáš Moravec, the Faculty of International Relations, University of Economics, Prague. Research fields: European and Business Law, Insolvency Law

** Jan Pastorčák, the Faculty of International Relations, University of Economics, Prague. Research fields: European and Business Law, Consumer Law

${ }^{* * *}$ Petr Valenta, the Faculty of International Relations, University of Economics, Prague. Research fields: Business Law and Insolvency Law

${ }^{1}$ Council Regulation (EC), No 1346/2000 of 29 May 2000 on insolvency proceedings.
} 
credit institutions, investment undertakings which provide services involving the holding of funds or securities for third parties, or to collective investment undertakings hereinafter financial institutions. The failure of financial institutions is govern by other directives.

The European Regulation No. 1346/2000 governs international jurisdiction rules, recognition of opening insolvency proceeding rules and rules concerning the cooperation between courts and insolvency trustees. Under the scope of international jurisdiction falls also the question of insolvency status for regular insolvency proceedings.

The basic conflict rule is contained in the Art. 4 of the Regulation No. 1346/2000 that states:

The law applicable to insolvency proceedings and their effects shall be that of the Member State within the territory of which such proceedings are opened.

So insolvency proceedings are governed by the law of the State in which it was launched. The opened insolvency proceeding sets insolvency status. Furthermore insolvency status shall govern in particular the initiation, conduct and termination of insolvency proceedings.

As a connecting factor for setting insolvency status in the Regulation No. 1346/2000 is selected center debtor's main interests. The European Regulation No. 1346/2000 in Art 3states:

The courts of the Member State within the territory of which the centre of a debtor's main interests is situated shall have jurisdiction to open insolvency proceedings. In the case of a company or legal person, the place of the registered office shall be presumed to be the centre of its main interests in the absence of proof to the contrary.

The opening of insolvency proceeding in the European Union Member state has universal effect and causes the impossibility of opening another main insolvency proceeding in other Member state. There should exist ideal situations in which only one single proceeding with a universal effect is commenced $^{2}$. Therefore, the word opening should have been judged in the autonomous sense used in the Regulation No. 1346/2000.

According to Art. 1 of the European Regulation No. 1346/2000 shall apply to collective insolvency proceedings which entail the partial or total divestment of the debtor and the appointment of a liquidator. Insolvency proceedings that meet the above definition are listed in Appendix A of the Regulation No. 1346/2000. If the procedure is not mentioned in the Annex of bankruptcy, does not fall under its scope as expressed by the European Union Court of Justice (Case C-461/11 Radziejewski [2012] ECR,

\footnotetext{
${ }^{2}$ Moss, Fletcher, IsAacs, EC RegUlation On InsOlvency ProceEdings 246 (2nd ed., OUP 2009)
} 
paragraph 38).

Garcimartin (2011, at 28) mentions different mechanisms to deal with a debtor in financial difficulties. He reduced the mechanisms into three main techniques depending on the degree of judicial intervention as follows:

(i) on the one hand, out-of-court restructuring;

(ii) on the other hand, formal insolvency proceedings and, between these two extremes,

(iii) hybrid procedures. ${ }^{3}$

The goal of the article is factual analysis of insolvency status in hybrid proceeding across the European Union. Firstly the article is focused on hybrid proceeding in European Union Member states and criterion for establishing of insolvency status. Secondly the article deals with hybrid proceeding from the view of the current Regulation No. 1346/2000 and from the view of proposal of the Regulation No. 1346/2000 revision ${ }^{4}$.

We set the hypothesis that hybrid proceeding should be involved under the scope of the Regulation No. 1346/2000. The paper is based on factual analysis of legislation and structural analysis of court decisions.

The question of insolvency status is not solved complexly in literature and other researches. Moss, Fletcher and Isaacs ${ }^{5}, 2009$ have focused especially on COMI, forum shopping and applicable law on insolvency proceedings. Eidenmüller ${ }^{6}$ has analyzed the choice of insolvency status according the Regulation No. 1346/2000. Eidenmüller ${ }^{7}$ has reviewed a proposal of amendment of the Regulation No. 1346/2000 and concluded that Regulation No. 1346/2000 could not regulate hybrid insolvency proceedings. Varriale $^{8}$ has examined impact of proposal of Regulation No. 1346/2000 revision on the schemes of arrangement and tried to foresee future

\footnotetext{
${ }^{3}$ F. Garcimartin, The Review of EU Insolvency Regulation: Some General Consideration and Two Selected Issue (Hybrid Procedures and Netting Arrangements), in L. LENNARTS; F. Garcimartín, The Review of the EU Insolvency Regulation: Some Proposals for Amendment, NETHERLANDS ASSOCIATION FOR COMPARATIVE AND INTERNATIONAL INSOLVENCY LAW, s. 28 (2011). Available at http://www.naciil.org/publications/preadviezen-reports-2011/ (last visited Feb 8, 2015).

${ }^{4}$ 2012/0360/COD Proposal for a Regulation of the European Parliament and of the Council amending Council Regulation (EC) No 1346/2000 on insolvency proceedings.

${ }^{5} \mathrm{See}$ footnote 1 .

${ }^{6}$ H. Eidenmüller, Free Choice in International Company Insolvency Law in Europe, EUROPEAN Business Organization Law REview 440 (June 2005).

${ }^{7}$ H. Eidenmüller, A New Framework for Business Restructuring in Europe: The EU Commission's Proposals for a Reform of the European Insolvency Regulation and Beyond, MAASTRICHT JOURNAL. Available at http://www.maastrichtjournal.eu/ (last visited Feb 8, 2015).

${ }^{8}$ G. Varriale, Scheme of Arrangement under Threat, InTERNATIONAL FinANCIAL LAw REviEW 97 (2013).
} 
development of this institute. Moravec ${ }^{9}$ has examined the possibility of choice of insolvency regime in hybrid proceeding by entrepreneurs.

\section{HYBRID PROCEEDING}

As was mentioned above, hybrid proceeding ranks between the concept out of the court restructurings and formal insolvency proceedings before court. Usually in hybrid proceeding, debtors in financial difficulties renegotiate their contracts with their creditors under supervision of insolvency court.

Any debtor in financial difficulties can always renegotiate with his creditors the terms and conditions of their contracts. These modifications may result, for example, in a rescheduling of payments, a reduction of their interest rates, a total or partial debt write-off or new loan facilities. The concept out-of-court restructurings do not involved court supervision.

It is important to mention that out of court restructuring involved voluntary agreement between debtor and creditor according their will without any coercion. From this view law according the Regulation No. $593 / 2008^{10}$ should be applied on this agreement. As was mentioned above formally judicial insolvency proceedings entails the partial or total divestment of a debtor and the appointment of a liquidator and are mention in Appendix A of the Regulation No. 1346/2000.

Therefore, there are different opinions whether hybrid proceeding should be govern by the law applicable to the corresponding contract according the Regulation No. 593/2008 or should be govern by the law applicable to the insolvency proceeding according the Regulation No. $1346 / 2000$.

In view of the fact that this hybrid proceeding includes elements of contract law and some aspects of formal insolvency proceedings, it raises some fundamental questions. Firstly, it is necessary to determine in these proceedings jurisdiction, applicable law, and also the need to ensure the recognition and enforcement of rights and obligations arising from these hybrid procedures.

If the hybrid proceeding is not recognize by European insolvency regulation it could cause the undesirable situation that several hybrid proceedings might be commenced in the different European Union Member states.

\footnotetext{
${ }^{9}$ T. Moravec, The Choice of Insolvency Regime in Hybrid Proceeding by Entrepreneurs, 2 (57) THE JURIDICAL CURRENT JOURNAL XVII (2014).

${ }^{10}$ Regulation (EC) No 593/2008 of theEuropeanParliament and of theCouncil of 17 June 2008 on the law applicable to contractual obligations (Rome I).
} 


\section{A. Hybrid Proceeding in the Member States}

It is important to distinguish the hybrid proceeding from a preinsolvency proceeding. Pre-insolvency proceeding is only formal proceeding regulated by insolvency law, which give a debtor in financial difficulties the opportunity to restructure and recover himselve at a preinsolvency stage under the supervision of a court or an administrative authority.

Hybrid proceedings which are not found in the Annex A of the European insolvency regulation in European Union Member state areas follow. In Belgium, hybrid proceeding is called Réorganisation judicaire par accord amiable and is based on the negotiation of settlements with all or some of the company's creditors negotiated on a case-by-case basis takes place under the court's supervision. French procedure sauvegarde financiére accélérée is capable of imposing a restructuring plan relatively quickly on minority hold-out financial creditors, as the procedure provides for the implementation of what is, essentially, a pre-negotiated plan. This procedure only applies to financial creditors. Hybrid proceeding regulated by the German law is called Schutzschirmver fahren. This proceeding is based on continuation of business operations and the implementation of the restructuring process without debtor's suffering any loss of control. Italian proceeding concordato preventive involves creditor arrangement that provide for the continuation of the business of the company in financial distress approved by court.

In Luxembourg, there is the procedure which is called concordat préventif de faillite. This is a procedure which is opened to a debtor who finds himself in a bankrupt situation, but wants to avoid bankruptcy through a composition with its creditors.

In Netherland, it is possible to apply the hybrid proceeding only for natural person and this proceeding is called Schuldaner ingsregeling.

Furthermore hybrid proceeding is regulated in Poland Postepowanie naprawcze, which relates to distressed companies and judicial composition proceedings for companies only jeopardized by insolvency. Portuguese law involves also hybrid proceeding Processo Especial de Revitalização that involves formal legal framework for companies in financial distress to negotiate agreement with their creditors. In Romanian law hybrid proceeding is called concordat préventif. This hybrid proceeding covers certain agreements made between the insolvent debtor and its lenders as part of a debt restructuring scheme and cannot be challenged by insolvency officials. Spain Homologación de los acuerdos de refinanción allows 
operationally viable companies to comprehensively transform their unsustainable financial burden into sustainable debt, whilst respecting the rights of creditors to maximize the recovery of their debt from these companies. This incorporation may finally stop the exodus of Spanish viable companies with financial difficulties to the UK, to be rescued by the UK courts.

For natural person, it is possible to ask for hybrid proceeding also in Sweden which is called schuldanering.

Hybrid proceeding is also regulated in the United Kingdom under the name Scheme of arrangement. The scheme of arrangement is an agreement between a company and either the holders of its securities or its creditors which has to be approved by a court ${ }^{11}$. The similar proceeding is regulated also by the Maltese law that is called Rikostruzzjonijiet ta' Kumpaniji.

Other European Union member states do not regulate this type of insolvency proceeding. Only eleven of twenty eight European Union Member states govern hybrid insolvency proceeding.

\section{B. Hybrid Proceeding in Case Law}

Hybrid proceedings are primary resolved by national courts because of this procedure are not recognize by European law. Minor reference corresponding to this issue is in case C-116/11 Bank Handlowy and Adamiak $^{12}$. General advocate argues that French proceeding sauvegarde is mentioned in Annex I of the European insolvency Regulation and the European Union Court of Justice closed about proceeding within scope of European insolvency regulation that:

... proceedings produce suniversal effects in that the proceedings apply to the debtor's assets situated in all the Member States. As long as main insolvency proceedings are pending, no other main proceedings may be opened.

Furthermore European Union Court of Justice in case C-461/11 Radziejewski ${ }^{13}$ concerns the hybrid proceeding Schuldanering in Sweden. This debt relief proceeding is not an insolvency procedure within the meaning of Article 1 of the European insolvency Regulation. European Union Court of Justice also mentioned in paragraph 35 that:

In that regard, it must be held that, to the extent that debt relief decisions do not fall within the scope of Regulation No 1346/2000 or that of Regulation No

\footnotetext{
${ }^{11}$ TOMÁŠ MORAVEC, SOUDNÍ PRAVOMOC V INSOLVENČNíM ŘÍZENÍ S EVROPSKÝM PRVKEM 124 (1st ed. Praha: TROAS 2012).

${ }^{12}$ [2012] ECR.

${ }^{13}$ [2012] ECR.
} 
44/2001, European Union law does not impose any obligation to recognise such a decision on the authorities of the other Member States.

In the case Cusp Ltd v. Toni and Guy (Ireland) Ltd, ${ }^{14}$ High Court of Justice in Northern Ireland decides about jurisdiction between Ireland and Northern Ireland courts. Defendant carried on its business activities in Ireland and was appointed interim examiner. Also separate administrative proceeding according Northern Ireland law was commenced and this proceeding is not mentioned in the Annex B of the Regulation No. $1346 / 2000$ and therefore the Regulation No. 1346/2000 could not be applied on this separate proceeding. High Court of Northern Ireland decided that insolvency status is at Ireland court and stated:

... purpose of the Regulation which, in my view, would be fundamentally thwarted if, despite being fully aware of the relevant proceedings, the plaintiff was entitled to simply ignore the efforts of all those concerned in an attempt to successfully preserve the existence of the defendant company and to later issue its own proceedings in a separate jurisdiction.

The District Court Hague ${ }^{15}$ commented recognition of the hybrid proceedings in the European Union which are not listed in Appendix A of the Regulation No 1346/2000. The court stated that there is no requirement for automatic recognition by the other Member States under the Article 16 of the Regulation No. 1346/2000. In opposite way Munich court decided in case BenQ Mobile that the hybrid proceeding had been involved under scope of the Regulation. ${ }^{16}$ Question of the insolvency status and recognition of judgment was solved also by English courts. In England, the procedure scheme of arrangement is very popular for overseas companies in financial distress. The criterions for application of the scheme of arrangement according to the English law are very flexible. Companies Act 2006 is based on the criterion of sufficient connection which is developed by English judges. English Court has the power to sanction the scheme of arrangement if the overseas company is liable to be wound up and if there is sufficient connection with England and Wales.

One of the most important decision of High court is case Rodenstock, ${ }^{17}$ in which scheme of arrangement was a sanction. According to Judge Briggs the jurisdictional restrictions imposed by the Regulation No 1346/2000 are not engaged. The effectiveness of the scheme of arrangement in binding the dissentient minority is unlikely to be achieved by automatic recognition of a

\footnotetext{
${ }_{14}^{14}$ [2010] NIQB 90.

${ }^{15}$ Rechts bank's Gravenhage 2010: BN 9604.

${ }^{16}$ Paulus Ch. EuInsVO: ÄNDERungen AM Horizont und IHRe Auswirkungen 297 (NZI 2012).

${ }^{17}$ [2011] EWHC $1104(\mathrm{Ch})$.
} 
sanction order under Regulation No. 44/2001 ${ }^{18}$.

Similar conclusion was reached in case PrimaCom ${ }^{19}$. The court stated that the scheme of arrangement might be recognized under Regulation No. 44/2001 and in paragraph 67 mentioned:

English law, that law governs not only the formation but also the extinction and restructuring of those debts, be it by fulfilment, settlement or, as in question, by a scheme of arrangement.

Questionable might be the compliance of sanctioned scheme of arrangement with the order public of Germany.

Furthermore High Court analyzed recognition of scheme of arrangement in case Apcoa Parking, ${ }^{20}$ in which the judge observed that according to Article 2 of the Regulation No. 593/2008, the parties to a contract dealing with civil and commercial matters. The judge also concluded that:

... regulation No. $1346 / 2000$ does not apply to schemes of arrangement. Furthermore, the Regulation No. 44/2001 does not limit the original jurisdiction of the English court, even though the application may be a civil or commercial matter.

Bundesgerichthof ${ }^{21}$ held that English scheme of arrangement has not qualified as insolvency proceeding but can be recognized by the Regulation No. $1215 / 2012^{22}$. Contrary to Bundesgerichthof LG Rottweil ${ }^{23}$ decided that scheme of arrangement might be recognized by the German insolvency law as foreign insolvency proceeding. This issue is not clear because of German court refused to recognize scheme of arrangement in the case Equitable life ${ }^{24}$.

\section{The InsOlVENCY StATUS IN THE HyBRID PROCEEDING}

The insolvency status is set in the time of opening insolvency proceeding. The insolvency status sets applicable law which governs the agreement between creditors and debtor. From the view of the Regulation No. 1346/2000 the time of opening of proceedings is the time at which the

\footnotetext{
${ }^{18}$ Council Regulation (EC) No 44/2001 of 22 December 2000 on jurisdiction and the recognition and enforcement of judgments in civil and commercialmatters.

${ }^{19}$ [2011] EWHC 3746 (Ch).

${ }^{20}$ [2014] EWHC 3849.

${ }^{21}$ IV ZR 194/09.

${ }^{22}$ Regulation (EU) No 1215/2012 of 12 December 2012 on jurisdiction and the recognition and enforcement of judgments in civil and commercialmatters.

${ }^{23} 3 \mathrm{O} 2 / 08$.

${ }^{24}$ OLG Celle 8 U 46/09.
} 
judgment about insolvency becomes effective in other European Union Member states and it is the moment when we are not able to speak about hybrid insolvency proceeding.

The insolvency status is set by connecting factor. As was above mentioned it can be derived by the Regulation No. 593/2008.

The recognition and enforceability of hybrid proceeding in European jurisdictions is uncertain albeit would most likely be recognizable under the Regulation No. 1346/2000 or under the Regulation No. 1215/2012.

\section{A. The Current Legislation}

According to the Regulation No. 1346/2000 it is important for setting the insolvency status that within the territory of the European Union Member states is located COMI. This principle is applied on the insolvency proceeding in the scope of Regulation No. 1346/2000. There are also hybrid proceedings that do not fall within scope of the Regulation No. 1346/2000, and the connection to the law of the European Union Member states is regulated by national legislation ${ }^{25}$. The European Court of Justice told that the Regulation No. $1346 / 2000$ is not able to use for national procedure which are not listed in Annex $\mathrm{A}^{26}$.

Therefore, the debtor has a possibility to change insolvency status in hybrid procedure when fulfill condition set by the national legislation. On one hand the fulfilling of specific condition for setting the insolvency status can be very easy. In English legislation it is enough to change governing law of financial documents to be subject of English jurisdiction. English judges developed one more condition that company shall provide expert evidence that the relevant foreign jurisdiction will recognize the scheme of arrangement. This possibility of changing the insolvency status could also lead to the creation of speculative loans.

On the other hand, there is an uncertainty of recognition of hybrid procedure in the European Union Member states because of procedure is based on contractual basis. Therefore hybrid procedure might be recognized under Regulation No. 1215/2012. This issue is not clear because of German court refused to recognize scheme of arrangement in the case Equitable life ${ }^{27}$ and also Dutch court mention that hybrid proceeding could not be automatically recognize ${ }^{28}$. On the other hand the German courts recognized

\footnotetext{
${ }^{25}$ See footnote 7.

${ }^{26}$ C-461/11 Radziejewski, [2012] ECR.

${ }^{27}$ See footnote 19.

${ }^{28}$ See footnote 12 .
} 
hybrid proceeding of Rodenstock $\mathrm{GmbH}^{29}$ and PrimaCom ${ }^{30}$.

\section{B. The Proposed Legislation}

The revision of the Regulation No. 1346/2000 undergoes through legislative procedure under the No. 2012/0360/COD. The revised Regulation shall apply to collective judicial or administrative proceedings, including interim proceedings, which are based on a law relating to insolvency or adjustment of debt, for the purpose of avoidance of liquidation, adjustment of debt, reorganization or liquidation. So the scope of revised Regulation should be extended also to hybrid and pre-insolvency proceedings as well as debt discharge proceedings and other insolvency proceedings for natural persons, which currently do not fit the definition. According to the COM 744, 2012 the European Union Member states should notify the hybrid proceedings which should be included under the new definition of the scope of the EU Insolvency Regulation. So the European Union Member states might refrain from this notification and might maintain the status quo and the current possibilities or tools in their national legislation will live their own lives. From our point of view this type of regulation is not convenient because of this way does not solve above mentioned pitfalls ${ }^{31}$.

Paulus ${ }^{32}$ mentioned that scheme of arrangement should be involved under scope of the Regulation No. 1346/2000 because of nature of this proceeding is contractual.

We think that the EU Insolvency Regulation should regulate all insolvency proceedings as hybrid as classical. Samuel Bufford ${ }^{33}$ proposed that should be enacted also tertiary proceeding, which shall include hybrid proceeding in case that main proceeding was commenced.

\section{CONCLUSION}

We conclude that hybrid proceedings are regulated by national law and could not be automatically recognize. Therefore there could be positive or negative conflicts of insolvency status. There is supposing that agreement

\footnotetext{
${ }^{29}$ [2011] EWHC 1104 (Ch).

30 [2011] EWHC 3746 (Ch).

31 See footnote 7.

${ }^{32}$ See footnote 13.

${ }^{33}$ Samuel Bufford, Revision of the European Union Regulation on Insolvency ProceedingsRecommendations, Penn State Law Research Paper 2-2014. Available at http://ssrn.com/abstract=2382133 (last visited Feb 8, 2015).
} 
between creditors and debtor should be recognized under Regulation No. $1215 / 2012$.

Further we found that the hybrid proceeding should be regulated in European legislation. First possibility is to involve this procedure into the Regulation No. 1346/2000 as assume proposal of Regulation No. 1346/2000. The second option is also regulate the hybrid proceeding but separately from the insolvency proceeding at the European level.

Another reason for regulation of the hybrid proceeding is avoid the negative forum shopping. We believe that in the case of a positive change of insolvency statute provided a higher satisfaction of the creditors or the fulfillment there should be possibility to move the insolvency statute. We also think that this change could be made by voting of creditors ${ }^{34}$. We believe that the choice of the insolvency statute might be permissible if it is to favor certain qualified quorum of creditors who own large and small claims, and that choice would have to be a forum for the benefit of all creditors. It would be a positive forum shopping, which is desirable ${ }^{35}$. Choosing the insolvency statute may be desirable in some situations and can also bring lower transaction costs. The changing of insolvency status also supports Munciarelli. ${ }^{36}$ Eidenmüller suggest that it is possible to change the insolvency status by changing the articles of association and creditors could predict this fact. ${ }^{37}$

\footnotetext{
${ }^{34}$ See footnote 7.

${ }^{35}$ T. Moravec, J. Pastorčák, Insolvency Status in Hybrid Proceeding at Dny Práva Conference, 2014, Brno.

${ }^{36}$ F. M. Muncciarelli, Not Just Efficiency: Insolvency Law in the EU and Its Political Dimension, 2 EUROPEAN BUSINESS ORGANIZATION LAW REVIEW, s. 191 (2013).

${ }^{37}$ See footnote 4.
} 